\title{
Necrotic death as a cell fate
}

\author{
Wei-Xing Zong ${ }^{1}$ and Craig B. Thompson ${ }^{2,3}$ \\ ${ }^{1}$ Department of Molecular Genetics and Microbiology, State University of New York at Stony Brook, Stony Brook, New \\ York 11794, USA; ${ }^{2}$ Abramson Family Cancer Research Institute, University of Pennsylvania, \\ Philadelphia, Pennsylvania 19104, USA
}

\begin{abstract}
Organismal homeostasis depends on an intricate balance between cell death and renewal. Early pathologists recognized that this balance could be disrupted by the extensive damage observed in internal organs during the course of certain diseases. This form of tissue damage was termed "necrosis", derived from the Greek "nekros" for corpse. As it became clear that the essential building block of tissue was the cell, necrosis came to be used to describe pathologic cell death. Until recently, necrotic cell death was believed to result from injuries that caused an irreversible bioenergetic compromise. The cell dying by necrosis has been viewed as a victim of extrinsic events beyond its control. However, recent evidence suggests that a cell can initiate its own demise by necrosis in a manner that initiates both inflammatory and/or reparative responses in the host. By initiating these adaptive responses, programmed cell necrosis may serve to maintain tissue and organismal integrity.
\end{abstract}

Up until 1971, the term "necrosis" was used for all types of cell death. When Kerr (1971) et al. first observed a form of nonpathologic cell death in certain tissues, they termed it shrinkage necrosis. As shrinkage necrosis became implicated in the control of organ homeostasis, it was renamed apoptosis (Kerr et al. 1972). Over the last three decades, apoptotic cell death has been well characterized at both the genetic and biochemical levels. These studies have demonstrated that while apoptosis is often initiated in response to toxic insults, the ultimate fate of the injured cell is self-determined. During apoptosis, the injured cell degrades its internal constituents and signals for the clearance of the resulting corpse through phagocytosis. While apoptotic cell death has become increasingly well defined, our notions of necrotic cell death has become progressively more vague. At present, the most widely accepted way to define necrotic cell death is to show that the death was not mediated by apoptosis (Table 1).

Morphologic description using light or electron microscopy remains the best way to define necrosis and

[Keywords: ROS; calcium; mitochondria; necrosis]

${ }^{3}$ Corresponding author.

E-MAIL craig@mail.med.upenn.edu; FAX (215) 746-5511.

Article and publication are at http://www.genesdev.org/cgi/doi/10.1101/ gad.1376506. contrast it with apoptosis. Apoptosis is characterized morphologically by pyknosis (deep staining of nuclear mass), nuclear fragmentation, and formation of condensed cell bodies (apoptotic bodies). This ordered morphology depends on the ability of the dying cell to engage in ATP-dependent processes of self-degradation. In contrast, necrosis can be defined morphologically by electron-lucent cytoplasm, swelling of cellular organelles, and loss of plasma membrane integrity (Table 1). These events can be reproduced experimentally by impairing a cell's ability to produce ATP. Because of these morphological and bioenergetic differences, apoptosis is now widely regarded to be analogous to an active or programmed form of cell death. In contrast, necrosis has come to be referred to as a form of cell death that is uncontrolled or pathological. The concept that necrosis is unprogrammed is reinforced by the fact that necrotic cell death can be caused by exposures of cells to supraphysiological conditions such as mechanical force, heat, or cold.

Recent studies have demonstrated that in response to a given death stimulus, there is often a continuum of apoptosis and necrosis. Many insults induce apoptosis at lower doses and necrosis at higher doses. Even in response to a certain dose of death-inducing agent, features of both apoptosis and necrosis may coexist in the same cell. In addition, if not engulfed by neighboring cells or in cell culture, where phagocytosis does not usually happen, dead cells in the late stages of apoptosis may present necrotic features due to the loss of cellular energy and plasma membrane integrity. This process is called "apoptotic necrosis" or "secondary necrosis" (Majno and Joris 1995).

Despite the idea that necrosis is an uncontrolled or default form of cell death, accumulating studies have suggested that this may not be true. Rather, it appears that necrotic cell death can be a regulated event that contributes to development and to the maintenance of organismal homeostasis. Terms such as autolysis, oncosis (Majno and Joris 1995), pyroptosis (Cookson and Brennan 2001), necrapoptosis (Lemasters 1999), and necroptosis (Degterev et al. 2005) have been used to describe modes of nonapoptotic cell death that display aspects of programmed cellular suicide. In this review, we discuss the evidence that metazoan cells can initiate their own death by necrosis. The genetic components of this pro- 
Table 1. Comparison of apoptosis and necrosis as two distinct modes of programmed cell death

\begin{tabular}{|c|c|}
\hline Apoptosis & Necrosis \\
\hline (1) Energy-dependent-organized & $\begin{array}{l}\text { (1) Bioenergetic } \\
\text { impairment-disordered }\end{array}$ \\
\hline $\begin{array}{l}\text { (2) Plasma membrane } \\
\text { integrity maintained }\end{array}$ & $\begin{array}{l}\text { (2) Plasma membrane } \\
\text { integrity lost }\end{array}$ \\
\hline (3) Ordered DNA degradation & $\begin{array}{l}\text { (3) Random DNA } \\
\text { degradation }\end{array}$ \\
\hline $\begin{array}{l}\text { (4) Immuno-suppressive; e.g., } \\
\text { lysophosphatidylcholine } \\
\text { (LPC) }\end{array}$ & $\begin{array}{l}\text { (4) Immuno-stimulating; e.g., } \\
\text { high mobility group } \\
\text { protein B1 (HMGB1) }\end{array}$ \\
\hline $\begin{array}{l}\text { (5) Cell elimination; e.g., } \\
\text { phosphatidylserine (PS) }\end{array}$ & $\begin{array}{l}\text { (5) Initiation of cell growth } \\
\text { and tissue repair; e.g., } \\
\text { hepatoma-derived growth } \\
\text { factor (HDGF) }\end{array}$ \\
\hline
\end{tabular}

Apoptosis is energy-dependent. In dying cells, the plasma membrane integrity is maintained, and the intracellular content such as DNA is degraded in an orderly fashion. Molecules such as PS are exposed on the plasma membrane to facilitate the engulfment of apoptotic cells via phagocytosis, and molecules such as LPC are secreted to suppress immune response. Necrosis is characterized by bioenergetic catastrophe, which results in the cell demise in a disordered fashion. Molecules such as HMGB1 and HDGF are selectively released by the dying cells to stimulate immune response or activate wound repair.

grammed cell necrosis involve (1) gene products that function in the dying cell to induce an irreversible bioenergetic compromise that results in cell death, and (2) gene products that are selectively released into the extracellular environment to trigger a host response. The evolutionary advantage conferred by necrosis is that it allows cells to actively recruit a defensive or a reparative response to regions of multicellular organisms that have sustained damage or invasion. Programmed cell necrosis can be a consequence of extracellular signaling or can be initiated as a form of cellular suicide in response to intracellular perturbations. Cell suicide by necrosis appears to have evolved to allow multicellular organisms to have an early warning system to recognize and adapt to events that might compromise the integrity of the organism as a whole. As such programmed cell necrosis plays a role in a number of disease processes including vascular-occlusive disease, neurodegenerative diseases, infection, inflammatory diseases, exposures to toxins, and cancer (Majno and Joris 1995; Proskuryakov et al. 2002; Yuan et al. 2003).

\section{Physiological roles and significance of necrosis}

While mediators of necrosis such as calcium and reactive oxygen species (ROS) have been reported to contribute to apoptosis, recent studies have begun to demonstrate that the ability of such mediators to initiate necrotic cell death depends on active participation by the dying cell. The core events of necrosis are bioenergetic failure and rapid loss of plasma membrane integrity. These can result from defined molecular events that occur in the dy- ing cell, including increased mitochondrial ROS production, channel-mediated calcium uptake, activation of nonapoptotic proteases, and/or enzymatic destruction of cofactors required for ATP production. In addition, these necrotic mediators are often induced in the dying cell simultaneously and potentiate each other's ability to initiate the demise of the cell. Several physiological, pathological, and pharmacological conditions where necrosis may play an important role are discussed below.

\section{Vascular-occlusive disease}

Vascular-occlusive injury is caused by transient tissue ischemia due to obstruction of blood flow to a tissue, followed by reperfusion. Such events can lead to heart failure, brain damage, or limb loss (Neumar 2000). The ultimate consequence of transient vascular occlusion varies depending on the duration of ischemia and the extent of subsequent reperfusion. As a direct consequence of the ischemic phase, the glucose and oxygen supply becomes limited. Cells are forced to maintain ATP production by anaerobic glycolysis using glycogen stores and the remaining glucose in the surrounding tissue fluid (Dennis et al. 1991). This can lead to local tissue acidosis (Steenbergen et al. 1993; Gottlieb et al. 1996). As blood flow is re-established, the reintroduction of oxygen into the ischemic tissue leads to a burst of ROS production as a result of an acute increase of mitochondrial electron transport and enhanced activity of enzymes such as xanthine oxidase and NADPH oxidase (Zweier et al. 1987; Nordberg and Arner 2001). Hypoxia, glucose depletion, acidosis, and ROS production can all contribute to cell death. While these stress stimuli are known to contribute to apoptosis, they can lead to active necrosis as well (Neumar 2000; Padanilam 2003; Foo et al. 2005; Logue et al. 2005). Acidosis can result in $\mathrm{Ca}^{2+}$ influx by activating acid-sensing ion channels (ASICs) (Xiong et al. 2004). Sustained $\mathrm{Ca}^{2+}$ can stimulate mitochondrial dehydrogenases, impairing the cell's ability to suppress electron flux through the electron transport chain during hypoxia (McCormack et al. 1990). This enhanced level of NADH production contributes to a paradoxical increase in mitochondrial ROS production following reperfusion. Mitochondrial ROS can lead to disruption of mitochondrial inner membrane integrity and loss of the ability to generate ATP (Crompton et al. 1987; Griffiths and Halestrap 1995). Collectively, these events result in an active form of necrosis that initiates an inflammatory/wound repair response in the compromised tissue.

Recent evidence has confirmed that the necrotic cell death that occurs in such vascular injuries depends on the activity of genes acting in cis in the dying cell. For example, animals deficient in cyclophilin D (CypD), a component of the mitochondrial permeability transition (mPT) pore, are resistant to the necrotic, but not the apoptotic cell death that occurs during ischemia-reperfusion injury. Inhibition of CypD, or treatment with $\mathrm{Ca}^{2+}$ channel blockers or ROS scavengers can limit this 
form of necrotic cell death (Baines et al. 2005; Basso et al. 2005; Nakagawa et al. 2005; Schinzel et al. 2005).

\section{Excitotoxicity and neurodegenerative disease}

Cell death plays important roles in normal brain development as well as in central nervous system (CNS) disease (Oppenheim 1991; Sadoul 1998). At least two mechanistically different forms of cell death have been described in the CNS. Growth-factor deprivation-induced cell death contributes to the elimination of excess neurons at the completion of neural development (Purves et al. 1988). In this form of cell death, the loss of signal transduction from neurotrophic factors results in apoptotic cell death. In contrast, persistent excitation can lead to the death of mature neurons (Sattler and Tymianski 2001). Neuronal cells that are resistant to apoptosis as a result of a combined deletion of the required apoptotic factors Bax and Bak remain sensitive to excitotoxin-induced death (Lindsten et al. 2003). Excitotoxic cell death has the features of necrosis under these conditions.

Excitotoxicity results from the release of excess neurotransmitters and the engagement of cell membrane receptors with excitatory amino acids (EAA) such as ionotropic N-methyl-D-aspartate (NMDA), kainate, and 2-amino-3-propionate (AMPA). Excitotoxins share the property of inducing increased intracellular $\mathrm{Ca}^{2+}$ by releasing the endoplasmic reticulum (ER) $\mathrm{Ca}^{2+}$ pool and/or inducing transport of extracellular $\mathrm{Ca}^{2+}$ through plasma membrane transporters. Persistently elevated cytosolic $\mathrm{Ca}^{2+}$ has been implicated in excitotoxic cell death (Nicotera et al. 1999; Sattler and Tymianski 2001). In neurons, inhibition of $\mathrm{Ca}^{2+}$ uptake by mitochondria can suppress excitotoxic cell death (Stout et al. 1998). Excitotoxicity plays an important role in many CNS disorders, including seizures, trauma, and possibly neurodegenerative disorders such as Alzheimer's and Huntington's diseases.

\section{Viral and microbial infections}

During infection, a dynamic interaction between the pathogen and the host immune response occurs. While pathogens have evolutionarily developed strategies to facilitate their own survival and propagation, the hosts have also developed defense systems against the foreign invaders. Many pathogens have evolved ways to suppress host cell death in order to complete their life span and duplication cycles (Benedict et al. 2002; Cuconati and White 2002). This strategy is particularly important to viruses, since viruses are dependent on maintenance of host cell processes to sustain their replication cycle. However, some pathogens have also evolved ways to induce the death of cells of the host's immune system (Weinrauch and Zychlinsky 1999; Gougeon 2003). Most of this induced cell death has been characterized as apoptotic. However, recently, HIV-1 has been shown to kill CD4(+) T lymphocytes by necrosis rather than apoptosis (Bolton et al. 2002; Lenardo et al. 2002). Sindbis virus causes encephalomyelitis by inducing cell death in the central nervous system (CNS). There is evidence suggesting that the inflammatory aspect of the illness comes from necrotic cell death initiated by excitotoxic amino acids or ROS-mediated activation of poly/ADPribose) polymerase (PARP) (Irusta and Hardwick 2004; Griffin 2005).

Bacterial type III secretion systems (TTSS) are used by animal pathogens from the genera Shigella, Salmonella, and Yersinia to deliver specific bacterial proteins into host cells (Ipa in Shigella, Sip in Salmonella, and Yop in Yersinia). Such toxins are able to induce the death of infected macrophages (Phalipon and Sansonetti 2003; Guiney 2005; Zhang and Bliska 2005). In the case of Salmonella, this macrophage death can happen within $1 \mathrm{~h}$ of the infection. This rapid cell death appears to have features of necrosis and is dependent on the host cell's expression of caspase-1. The biological significance of this caspase-1-dependent necrosis has been discussed elsewhere (Boise and Collins 2001; Cookson and Brennan 2001; Jarvelainen et al. 2003; Hueffer and Galan 2004).

\section{Treatment of cancer}

The development of resistance to apoptosis is an important step in carcinogenesis. Despite this resistance, cancer therapeutic drugs are effective because of their ability to induce cancer cell selective death. Cancer biologists have begun to consider whether effective cancer therapeutics might induce cell death by activating necrosis. Approaches reported to be able to induce necrotic death in cancer cells include photodynamic treatment (PDT) and alkylating DNA-damaging agents (see below). Several other chemicals or agents such as $\beta$-lapachone, apoptolidin, and honokil also appear to induce cancer cell death through necrosis ( $\mathrm{Li}$ et al. 1999; Salomon et al. 2000; Tagliarino et al. 2001; Bai et al. 2003).

PDT involves administration of a photosensitizing molecules to the tumor (Uehlinger et al. 2000). Upon excitation with light from various spectra, the photosensitizer generates ROS (primarily singlet oxygen) that can lead to cell death. The preferential accumulation of certain photosensitizing compounds in tumor cells and the ability to treat only the defined tumor area make PDT a promising therapeutic approach to treat cancer patients. Numerous signaling pathways are activated in PDT-mediated cell death. PDT is effective even in cancer cells resistant to apoptosis. For example, apoptotic resistance induced by overexpressing Bcl-2/Bcl-xL does not prevent PDT-induced cell death, and a breast cancer xenograft lacking caspase-3 is sensitive to PDT treatment (Whitacre et al. 2002). Moreover, dead cells resulting from PDT treatment have been shown to possess potent immunogenicity (Gollnick et al. 2002). This is consistent with the pro-inflammatory effect of necrosis but not apoptosis.

PDT can induce necrosis at several levels (Agostinis et al. 2004; Almeida et al. 2004). When the photosensitization compounds are localized in the plasma membrane, cells die by necrosis due to the loss of plasma membrane integrity (Fabris et al. 2001; Hsieh et al. 2003). Activation 
of photosensitizers on lysosomes may disrupt the lysosomal membrane and result in the release of lysosomal proteases that may also lead to necrosis (Reiners et al. 2002). The majority of the PDT lethality appears to result from mitochondrial damage. Upon PDT treatment, both loss of mitochondrial inner membrane potential (mPT) and release of cytochrome c have been observed. However, as in many other situations, cytochrome c release and $\mathrm{MPT}$ in response to PDT may occur independent of each other (Chiu and Oleinick 2001), with mPT contributing to necrosis. Another factor that contributes to the onset of necrosis is intracellular $\mathrm{Ca}^{2+}$. Multiple mechanisms have been proposed to account for the intracellular $\mathrm{Ca}^{2+}$ increase.

A cell's resistance to PDT-induced necrosis can be modulated. ROS scavengers can protect cells from PDT, while inhibition of superoxide dismutase (SOD) increases cell sensitivity to PDT (Miccoli et al. 1998; Golab et al. 2003). The mPT inhibitor cyclosporine $\mathrm{A}$ and $\mathrm{Ca}^{2+}$ chelator BAPTA also suppress cell death in response to PDT treatment (Inanami et al. 1999; Belzacq et al. 2001).

DNA-alkylating agents are the most widely used and effective chemotherapeutic drugs used in cancer treatment (Chabner and Longo 2005). The mechanisms by which DNA-damaging agents affect tumor survival remain controversial. Several mechanisms for tumor-selective cell death in response to DNA alkylators have been proposed, including p53-mediated apoptosis, mitotic catastrophe, and PARP-mediated necrosis. Among these, the p53-mediated pathway is best understood, yet does not address why cancer cells that lack functional p53 remain sensitive to DNA-damaging agents. Mitotic catastrophe is defined as cell death resulting from aberrant cell mitosis in cancer cells that are usually defective in their mitotic checkpoint and will attempt to undergo cytokinesis without completing DNA repair. The molecular signature for mitotic catastrophe remains to be clearly defined and this form of cell death may share intermediates with apoptosis and/or necrosis.

The nuclear enzyme PARP can also initiate cell-autonomous necrosis. PARP is activated by DNA strand breaks, resulting in destabilization of the surrounding chromatin and allowing DNA repair enzymes access to the damaged DNA (de Murcia and Menissier de Murcia 1994). While inhibition of PARP may lead to tumor development by promoting genomic instability (de Murcia et al. 1997; Wang et al. 1997) or may contribute to cell death as an anti-tumor strategy in cells lacking other components of DNA repair (de Murcia et al. 1997; Bryant et al. 2005; Farmer et al. 2005), acute activation of PARP can induce necrosis (Ha and Snyder 1999). PARP activation results in necrosis by depleting the cellular NAD pool. This results in tumor selective cell death, because proliferative tumor cells are dependent on cytosolic NAD to maintain the ability to metabolize glucose and produce ATP. PARP depletion of cytosolic NAD prevents cells from using glucose as a metabolic substrate (Zong et al. 2004). Inhibition of PARP activity using PARP inhibitors or RNA interference (RNAi) confers resistance to necrosis induced by DNA-alkylating agents.

\section{Embryonic development}

While apoptosis plays an important role in tissue remodeling during embryonic development, whether necrosis also contributes to development remains a subject of debate. Evidence exists that apoptosis may not be the only form of cell death to eliminate unwanted cells during embryogenesis. Gene disruption of Apaf-1 results in perinatal lethality, however, digit separation, which depends on the death of interdigital web cells, still occurs (Cecconi et al. 1998; Yoshida et al. 1998). The dead cells in the interdigital area in Apaf-1-deficient embryos appear to be necrotic. The same result is obtained when wildtype embryos were cultured in the presence of the caspase inhibitor z-VAD-fmk (Chautan et al. 1999). Studies using z-VAD-fmk or caspase-3-deficient embryos suggest that necrosis may also be involved in inner ear development (D. Fekete and M. Bever, pers. comm.). The potential of necrosis to contribute to embryonic development has not been extensively investigated. Surprisingly, mice deficient in both multidomain proapoptotic Bax and Bak, in which the mitochondrial apoptosis pathway is completely blocked, are born with relatively normal tissue development and grow to adulthood (Lindsten et al. 2000). This suggests that a form of cell death independent of the mitochondrial apoptosis pathway can compensate for the lack of apoptotic death in these animals.

\section{Molecular mechanisms of programmed cell necrosis}

The fundamental feature that distinguishes most forms of necrosis from apoptosis is the rapid loss of cellular membrane potentials. The inability to maintain these electrochemical potentials results in cytoplasmic swelling, rupture of the plasma membrane, and cytolysis. This loss of membrane potentials may be a consequence of cellular energy depletion, damage to membrane lipids, and/or loss of function of homeostatic ion pumps/channels. These defects can synergize in the induction of necrotic cell death. For example, defective ATP production and/or excessive ATP consumption can lead to a decline in function of the ATP-dependent ion pumps on the plasma membrane. Perturbation of intracellular ion homeostasis can result in mitochondrial dysfunction and diminished ATP production. It is often difficult to determine whether the loss of ATP production or the disruption of channel function occurs first.

\section{Energy failure as a cause of necrosis}

The decline in function of the ATP-dependent ion pumps in the cytoplasmic membrane can lead to the opening of a so-called death channel in the cytoplasmic membrane that is selectively permeable to anions and inhibitable by glycine (Nishimura and Lemasters 2001). The opening of the death channel results in colloid osmotic forces and entry of cations that drive the cytoplasmic membrane swelling, and ultimately rupture.

Cellular stress resulting from nutrient starvation or a reduced oxygen supply often results in ATP depletion. 
Necrosis is often observed in the internal regions of tumors where nutrient and oxygen supplies are limited. In cultured cells, nutrient deprivation or growth factors withdrawal leads to apoptotic cell death initiated by proapoptotic Bcl-2 proteins (Lindsten et al. 2000; Rathmell et al. 2000, 2003; Wei et al. 2001). When the apoptotic machinery is inhibited by overexpressing anti-apoptotic Bcl-2 family members such as Bcl-2 and Bcl-xL, or by knocking out the proapoptotic members Bax and Bak, cells can maintain themselves transiently by autophagy. Cellular autophagy allows cells to maintain bioenergetics and viability by consuming their own intracellular macromolecules (Rathmell et al. 2000; Lum et al. 2005). However, the cells die by necrosis when their intracellular supply of metabolic substrates are depleted, unless nutrients and/or growth factors are restored to the culture medium (Lum et al. 2005).

Manipulating cell metabolism and ATP generation/ consumption can regulate cell fate. In healthy cells, the ATP levels are in the millimolar range, and as a result, no single biochemical reaction can instantly overwhelm the intracellular ATP pool. However, because cells depend on so many ATP-dependent reactions, ATP levels can rapidly decline if the cell's ability to generate ATP is impaired. Cells can generate ATP through oxidative phosphorylation and/or glycolysis. Oxidative phosphorylation occurs in the mitochondrial matrix, while glycolysis occurs in the cytosol. While oxidative phosphorylation is much more efficient in generating ATP from metabolites, glycolysis can generate ATP at a more rapid rate (Pfeiffer et al. 2001). A cell's ability to sustain itself by glycolysis is limited by its glucose supply and the rate at which the metabolic end product lactate can be cleared.

Vegetative cells can metabolize a variety of metabolic substrates to maintain ATP production through oxidative phosphorylation and can thus survive variations in glucose availability and metabolism without difficulty. However, because their ability to take up glucose is limited, vegetative cells adapt to changes in ATP demand slowly. In contrast, growing cells produce ATP almost exclusively from glucose (Bauer et al. 2004). Under most circumstances, their ability to take up glucose exceeds their metabolic needs. Because these cells can redirect the excess pyruvate that they normally secrete as lactate into the TCA cycle, growing cells have an enormous capacity to adapt to increased ATP demand. However, the ability of growing cells to degrade lipids and amino acids is limited because these substrates are redirected into synthetic processes. Thus, growing cells are dependent on glucose metabolism to sustain ATP levels.

\section{Inhibition of mitochondrial respiration induces necrosis in vegetative cells}

The mitochondrial respiratory chain transfers electrons from NADH-FADH ${ }_{2}$ to oxygen, generating a membrane potential across the mitochondrial inner membrane as protons are pumped across the inner membrane. The resulting electrochemical gradient drives protons back into the matrix through the $\mathrm{F}_{0} \mathrm{~F}_{1}$-ATPase generating ATP from ADP and Pi. Inhibition of mitochondrial respiratory chain activity results in reduced cellular ATP and can induce cell death by necrosis (Hartley et al. 1994; Woodgate et al. 1999; Ohgoh et al. 2000).

Mitochondrial permeability transition, also known as mitochondrial depolarization, is defined as the loss of transmembrane potential of the mitochondrial inner membrane (Haworth and Hunter 1979; Hunter and Haworth 1979a,b). mPT leads to the loss of the proton gradient and a shutdown of ATP generation through oxidative phosphorylation. Permeability transition (PT) pores open in the mitochondrial inner membrane in response to stimuli such as increased intracellular $\mathrm{Ca}^{2+}$, inorganic phosphate, alkaline $\mathrm{pH}$, and ROS.

The physiological function of the PT pore core complex remains poorly understood. As long as the PT pore is open, a cell cannot generate ATP by oxidative phosphorylation. While the opening of the PT pore has been proposed to amplify apoptosis by mediating release of mitochondrial apoptogenic factors, its persistent opening leads to necrotic cell death (Marzo et al. 1998; Narita et al. 1998; Pastorino et al. 1998). Although a number of papers have implicated the adenine nucleotide translocase (ANT), which mediates ADP-ATP exchange across the mitochondrial inner membrane as a component of the PT pore, $\mathrm{mPT}$ still occurs in the ANT-deficient mitochondria in response to several known $\mathrm{mPT}$ inducers such as calcium ionophores (Kokoszka et al. 2004), t-butylhydroperoxide (Halestrap et al. 1997), and diamide (McStay et al. 2002), indicating that ANT may not be essential for mPT. Studies have shown that death of ANT-deficient hepatocytes in response to $\mathrm{Ca}^{2+}$ occurs via a necrotic cell death pathway that is caspase independent and can be blocked by cyclosporine A (Kokoszka et al. 2004). Cyclosporine A binds to CypD and competes it away from the PT pore complex, thus inhibiting mPT (Nicolli et al. 1996; Halestrap et al. 1997). Alternatively, cyclosporine A may also inhibit the PPI activity of CypD, and thereby inhibit mPT (Clarke et al. 2002).

The potent inhibitory effect of Cyclosporine A on $\mathrm{Ca}^{2+}$-induced cell death in ANT-deficient cells indicates that CypD is a key regulator of mPT-related necrosis. Indeed, overexpression of CypD sensitizes a neuronal cell line to mPT and necrosis induced by $\mathrm{Ca}^{2+}$ and ROS, yet inhibits caspase activation and apoptosis. These results suggest that $\mathrm{mPT}$ may have opposite roles in inducing necrosis or apoptosis (Agostinis et al. 2004). This theory is supported by gene knockout studies. CypD deficiency renders cells resistant to necrosis induced by $\mathrm{H}_{2} \mathrm{O}_{2}$ and $\mathrm{Ca}^{2+}$ overload, and protects mice from cardiac ischemia-reperfusion injury, yet has no effect on the apoptotic machinery. In CypD-deficient cells, cytochrome $\mathrm{c}$ release and caspase activation occur normally following apoptotic stimuli $\mathrm{TNF} \alpha$, staurosporine, etoposide, and activation of proapoptotic Bcl-2 family members Bax, Bak, and tBid (Baines et al. 2005; Basso et al. 2005; Nakagawa et al. 2005; Schinzel et al. 2005). These genetic studies demonstrate that CypD-mediated $\mathrm{mPT}$ is a 


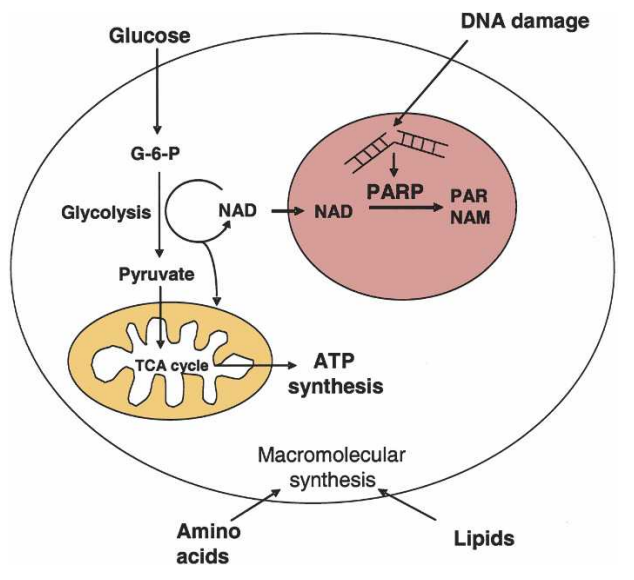

Figure 1. DNA damage-induced necrosis occurs selectively in growing cells. Highly proliferative cells utilize aerobic glycolysis for ATP production as other nutrient sources such as amino acids and lipids are redirected into synthetic reactions that support cell growth and proliferation. In response to alkylating DNA damage, the nuclear enzyme PARP is activated and degrades NAD into poly(ADP)-ribose polymers and nicotinic acid mononucleotide (NAM). The consumption of NAD depletes the cellular NAD pool and shuts down the cell's ability to degrade glucose to support ATP production, leading to necrosis.

key effector of cellular necrosis. How CypD becomes activated to induce $\mathrm{mPT}$ remains unclear. While $\mathrm{H}^{+}$inhibits $\mathrm{mPT}, \mathrm{Ca}^{2+}$ promotes it, suggesting possibilities that CypD may change conformation in response to acidification or as a result of $\mathrm{Ca}^{2+}$ binding.

These recent studies on CypD, together with studies on the Bcl-2 family of proteins, support the theory that the mitochondrion plays a key role in controlling both apoptosis and necrosis. While Bax and Bak function on the mitochondrial outer membrane to mediate the release of apoptogenic factors into the cytosol during apoptosis, CypD controls the PT pores on the inner membrane during necrosis.

\section{Necrosis in growing cells}

When mitochondrial respiration is inhibited, or under the circumstances where oxygen supply is limited, cells may switch from oxidative phosphorylation to glycolysis to generate ATP. Highly proliferating cells such as lymphocytes and tumor cells undergo net protein and lipid synthesis. As a result, they maintain ATP production almost exclusively through catabolizing glucose through a mixture of glycolysis and oxidative phosphorylation termed aerobic glycolysis (Holt 1983; Baggetto 1992). Inhibiting glycolysis in such cells induces necrosis. In addition, blocking glycolysis with 2-deoxyglucose can sensitize cells to necrotic death upon treatment with chemotherapeutic agents. In contrast, mitochondrial inhibitors have little effect on the viability of cells with a high level glycolytic rate, because the cells are capable of maintaining ATP levels without mitochondrial respiration (Shchepina et al. 2002).
One efficient way to shut down glycolysis is by activating PARP. In response to DNA damage, PARP is activated by binding to DNA strand breaks, and catalyzes poly(ADP)-ribosylation of a variety of proteins by converting NAD into NAM and ADP-ribose (D'Amours et al. 1999; Kim et al. 2005). Because cytosolic and mitochondrial NAD pools do not exchange freely across the mitochondrial inner membrane, PARP preferentially depletes the cytosolic NAD pool without affecting mitochondrial NAD. By depleting the cytosolic NAD pool, activation of PARP inhibits further glucose catabolism, preventing glucose-dependent ATP production (Berger et al. 1983). While activation of PARP induces necrosis (Ha and Snyder 1999), NAD replenishment rescues cells from PARP-mediated cell death (Du et al. 2003; Ying et al. 2003). Metabolites such as pyruvate and $\alpha$-ketoglutarate that can be metabolized independent of cytosolic NAD have been shown to preserve cell viability after PARP activation (Zong et al. 2004; Ying et al. 2005), confirming that PARP activation induces cell death by inhibiting glucose catabolism. Highly glycolytic cells are more sensitive to cell death than vegetative cells that rely on oxidative phosphorylation to generate their ATP, because excessive PARP activation shuts down glycolysis, but has little effect on mitochondrial respiration of nonglucosederived substrates (Fig. 1; Zong et al. 2004; Cipriani et al. 2005).

\section{Calcium as a mediator of necrotic cell death}

Intracellular $\mathrm{Ca}^{2+}$ is an important signaling molecule for numerous cell responses including necrosis. In certain pathological conditions, extracellular ligands can induce $\mathrm{Ca}^{2+}$-dependent necrosis. One good example is the exci-

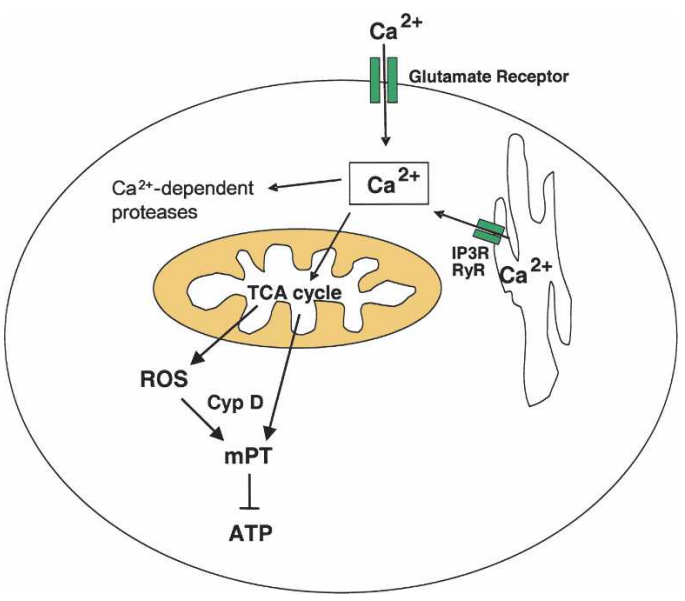

Figure 2. Calcium-mediated programmed necrosis. Intracellular calcium increases in response to the activation of ionotrophic glutamate receptors or through other calcium channels on the plasma membrane or the ER membrane. An intracellular calcium spike induces the activation of $\mathrm{Ca}^{2+}$-dependent proteases and stimulates mitochondrial TCA cycle activity and ROS production. If sustained, the resulting ROS leads to $\mathrm{MPT}$ that is dependent on CypD. mPT then leads to the loss of ATP production and necrosis. 
totoxic neuronal cell death induced by excitatory amino acids such as NMDA as detailed above (Fig. 2).

In viable cells the plasma and intracellular membranes are virtually impermeable to $\mathrm{Ca}^{2+}$. Under physiological conditions the $\mathrm{Ca}^{2+}$ concentration is $\sim 1.2 \mathrm{mM}$ extracellularly, and $\sim 0.1 \mu \mathrm{M}$ in the cytosol. Most of intracellular $\mathrm{Ca}^{2+}$ is stored in the ER. When the ER $\mathrm{Ca}^{2+}$ is released into the cytosol, or the extracellular $\mathrm{Ca}^{2+}$ crosses the plasma membrane, cell death can be initiated due to the activation of $\mathrm{Ca}^{2+}$-dependent proteases and/or mitochondrial $\mathrm{Ca}^{2+}$ overload. Extracellular $\mathrm{Ca}^{2+}$ can enter cells through three types of channels in the plasma membrane: voltage-gated channels controlled by the potential across the plasma membrane (Fatt and Ginsborg 1958), capacitive entry channels that are activated by the emptying of the ER $\mathrm{Ca}^{2+}$ store (Putney 1986; Berridge 1995), and the acid-sensing ion channels (ASICs) that belong to the degenerin/epithelial sodium channel superfamily (Deg/EnaC) (Waldmann et al. 1996; Bianchi et al. 2004; Yermolaieva et al. 2004). Calcium exclusion is maintained by the $\mathrm{Na}^{+} / \mathrm{Ca}^{2+}$ exchanger and plasma membrane $\mathrm{Ca}^{2+}$ pump (PMCA), also called the $\mathrm{Ca}^{2+}$ ATPase. To cross the ER membrane, the sarco/endo/plasmic reticulum $\mathrm{Ca}^{2+}$-ATPase (SERCA) is responsible for the uptake of $\mathrm{Ca}^{2+}$ from the cytosol into the ER lumen, while the inositol-1,4,5-trisphosphate (IP3) and the ryanodine receptor channels are responsible for the release of $\mathrm{Ca}^{2+}$ from the ER to the cytosol (Strehler and Treiman 2004; Saris and Carafoli 2005). PMCA and SERCA are ATP dependent, as they transport $\mathrm{Ca}^{2+}$ against its concentration gradient. Both the $\mathrm{Ca}^{2+}$ influx through the plasma membrane and $\mathrm{Ca}^{2+}$ release from the ER store can contribute to a cytosolic $\mathrm{Ca}^{2+}$ spike and mitochondrial overload.

$\mathrm{Ca}^{2+}$-mediated necrosis has been the best characterized form of programmed necrosis. In Caenorhabditis elegans, gain-of-function (hyperactive) mutants of the DEG/ENaC family members MEC-4 and MEC-10 [MEC4(d) and MEC-10(d)] induces necrosis of touch neurons (Driscoll and Chalfie 1991; Huang and Chalfie 1994). MEC-4(d)-induced neuronal cell death is independent of C. elegans apoptosis regulators, although genes required to remove the necrotic corpse are the same as those for the apoptotic corpse (Chung et al. 2000). Expression of MEC-4(d) induces $\mathrm{Ca}^{2+}$ influx and activates a $\mathrm{Ca}^{2+}$-induced ER $\mathrm{Ca}^{2+}$ release that leads to necrosis (Xu et al. 2001; Bianchi et al. 2004). In mammalian cells, $\mathrm{Ca}^{2+}$ has been shown to enter cells via voltage-sensitive L-type $\mathrm{Ca}^{2+}$ channels (Fryer et al. 1999), transient receptor potential (TRP) cation channels (Aarts et al. 2003), or ASIC (Xiong et al. 2004). These initial $\mathrm{Ca}^{2+}$ entries activate $\mathrm{Ca}^{2+}$-dependent proteases such as calpains to cleave the $\mathrm{Na}^{+} / \mathrm{Ca}^{2+}$ exchanger NCX that is required for extrusion of $\mathrm{Ca}^{2+}$. This leads to the inability for the cells to exclude $\mathrm{Ca}^{2+}$, hence the sustained intracellular $\mathrm{Ca}^{2+}$ increase (Bano et al. 2005). Thus, there exists a "self-amplification" of cytosolic $\mathrm{Ca}^{2+}$ spikes under these conditions. The prolonged cytosolic $\mathrm{Ca}^{2+}$ can trigger mitochondrial $\mathrm{Ca}^{2+}$ overload that leads to $\mathrm{mPT}$ and ATP depletion, as well as the activation of $\mathrm{Ca}^{2+}$-dependent proteases.
Like many other insults, increased cytosolic $\mathrm{Ca}^{2+}$ can initiate either apoptosis or necrosis. The outcome of cell death is probably determined by the concentration of cytoplasmic $\mathrm{Ca}^{2+}$. Whereas low to moderate $\mathrm{Ca}^{2+}(200-$ $400 \mathrm{nM}$ ) triggers apoptosis, higher concentration of $\mathrm{Ca}^{2+}$ $(>1 \mu \mathrm{M})$ is associated with necrosis (McConkey and Orrenius 1996). This may explain why $\mathrm{Ca}^{2+}$ released from the ER is mostly apoptotic, whereas $\mathrm{Ca}^{2+}$ influx through the plasma membrane is associated with necrosis. The mitochondrial metabolic status may also affect the sensitivity of mitochondria to $\mathrm{Ca}^{2+}$ poisoning and contribute to the determination of the death mode (Ankarcrona et al. 1995).

\section{ROS-initiated necrosis}

Cells in an aerobic environment are constantly generating ROS. Physiologic levels of ROS can regulate transcription, serve as signaling molecules, and defend against pathogen infection. Excessive production of ROS leads to oxidative stress, damage of intracellular molecules and organelles, and ultimately necrosis.

ROS include a number of molecules derived from oxygen. They include molecules with an unpaired electron, often termed free radicals. Some major species include superoxide $\left(\mathrm{O}_{2}^{-{ }^{-}}\right)$, hydrogen peroxide $\left(\mathrm{H}_{2} \mathrm{O}_{2}\right)$, hydroxyl radical $\left({ }^{\bullet} \mathrm{OH}\right)$, and nitric oxide $(\mathrm{NO})$. They are generated primarily in the electron-rich environment of the mitochondrial inner membrane, or through endogenous enzymes such as flavoenzymes, xanthine oxidase, NADPH-oxidase, glucose oxidase, nitric oxide synthase, or transition metals (Andreyev et al. 2005). ROS are neutralized by catalysis by endogenous enzymes such as superoxide dismutase (SOD), glutathione peroxidase, catalase, thioredoxin reductase, or by reacting with a free radical scavenger such as the endogenous glutathione and exogenous antioxidants (Nordberg and Arner 2001).

Mitochondria are a major source of ROS that can initiate necrosis. Excess mitochondrial ROS can damage DNA by causing cleavage of DNA strands, DNA-protein cross-linking, and oxidation of purines (Marnett 2000). This may lead to DNA-damage response, including activation of p53 and PARP. While activation of p53 may cause apoptosis and cell cycle arrest, hyperactivation of PARP leads to necrosis. Inhibition of PARP activity with inhibitors or gene knockdown blocks necrosis induced by $\mathrm{H}_{2} \mathrm{O}_{2}$ (Watson et al. 1995; Yu et al. 2002). PARPdeficient animals are resistant to ischemia-reperfusion injury (Endres et al. 1997). ROS also modify lipids, as the double bonds in polyunsaturated fatty acids are excellent targets for ROS attacks. Lipid oxidation can lead to the loss of integrity of both the plasma membrane and intracellular membranes such as that of lysosomes and the $E R$, leading to an intracellular leak of proteases or an influx of $\mathrm{Ca}^{2+}$ and resulting in necrosis. Another target of ROS are amino acid residues with sulfur or proteins with sulfhydral links. ROS can attack the disulfide bond, or break up the sulfhydral links, thereby changing the function of the modified proteins. ROS-mediated protein modification contributes to necrosis through modifying 
$\mathrm{Ca}^{2+}$ channels. Both the ER and plasma membrane $\mathrm{Ca}^{2+}$ channels have been shown to be affected by ROS, and the resulting influx of $\mathrm{Ca}^{++}$can trigger necrosis (Waring 2005).

A necrotic-signaling pathway that may involve ROS is death receptor-mediated necrosis (Fig. 3). In the field of apoptosis, the death receptor-mediated cell death is also referred to as "extrinsic pathway", which is initiated by the engagement of extracellular ligands with the cell death receptors on the plasma membrane (Nagata 1997). The most studied extrinsic death pathways are mediated by the TNF receptor (TNFR) super family. Upon binding of ligands such as TNF $\alpha$, the TNF receptor TNFR1 in the plasma membrane forms trimers and recruits several death domain-containing proteins to form the death-inducing complex (DISC).

One of the DISC components, FADD, has been shown to be involved not only in TNF $\alpha$-induced apoptosis, but also in necrosis. In the presence of caspase inhibitors, enforced oligomerization of FADD can induce necrosis (Kawahara et al. 1998), and this death is blocked in FADD-deficient $T$ cells (Holler et al. 2000). RIP1 is also involved in death receptor-induced necrosis, as RIP1-deficient $\mathrm{T}$ cells are also resistant to death induced by TNF $\alpha$ and FasL in the presence of caspase inhibitors (Holler et al. 2000). The kinase activity of RIP appears to be required for necrosis induction, although its targets remain to be identified. Necrostatin-1, a small molecule that can inhibit necrosis induced by RIP or by $\mathrm{TNF} \alpha$ and FasL in the presence of caspase inhibitor (Degterev et al. 2005), may help to uncover the signaling pathway involved in death receptor-mediated necrosis.

Despite the involvement of FADD and RIP1 in necrosis induction, the link between death-receptors activation and subsequent necrotic cell death remains poorly

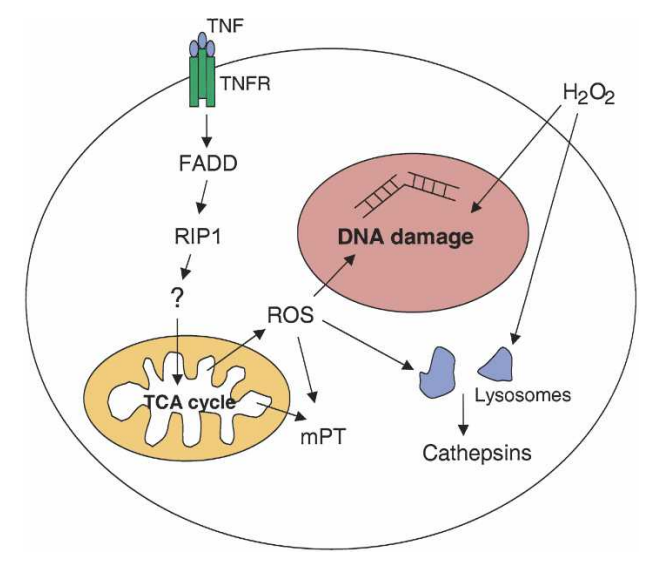

Figure 3. Immune response-induced programmed necrosis. During immune response, proinflammatory cytokines such as TNF can initiate signal transduction to the increase of mitochondrial ROS production, leading to DNA damage or lysosomal membrane pemeabilization. This can also be induced by $\mathrm{H}_{2} \mathrm{O}_{2}$ secreted by macrophages. Necrosis can result from the combined effects of DNA damage, mitochondrial depolarization, or lysosomal enzymes released into the cytosol. understood. One possible mechanism for death receptor-mediated necrosis is by generation of mitochondrial ROS. TNF $\alpha$ - and Fas-induced necrosis is prevented by a ROS scavenger butylated hydroxyanisole (BHA) (Vercammen et al. 1998; Goossens et al. 1999).

\section{Proteases involved in necrosis}

A number of proteases have been implicated in necrosis. Calpains and cathepsins are the major proteases involved in necrosis. Again, genetic evidence for the involvement of these proteases in necrosis came from studies in $C$. elegans. While gain-of-function mutations of the channel proteins DEG-1 and MEC-4, the acetylcholine receptor channel subunit proteins DEG-3, and the Gs protein GSA-1 induce necrosis in touch neurons of CED-3-deficient animals (Driscoll and Chalfie 1991; Treinin and Chalfie 1995; Korswagen et al. 1997; Berger et al. 1998), RNAi knockdown of CLP-1 and TRA-3 (homologs of mammalian calpain proteases) and ASP-3 and ASP-4 (homologs of mammalian cathepsin proteases) reduced the neuronal necrosis (Syntichaki et al. 2002).

\section{Calpains}

Calpains are a family of $\mathrm{Ca}^{2+}$-dependent cysteine proteases. There are at least 14 members that can be categorized into two subfamilies: $\mu$-calpains and m-calpains, which are named to reflect their requirements for $\mathrm{Ca}^{2+}$. $\mu$-Calpains are activated by micromolar and m-calpains by millimolar concentrations of $\mathrm{Ca}^{2+}$ (Suzuki and Sorimachi 1998; Goll et al. 2003). The two subfamilies share a common $30-\mathrm{kDa}$ regulatory subunit and contain a distinct $\sim 80-k D a$ catalytic subunit (Suzuki et al. 2004). Calpains reside in the cytosol as an inactive form. In response to increased levels of cytosolic $\mathrm{Ca}^{2+}$, calpains translocate to the intracellular membranes and are activated by autocatalytic hydrolysis. A number of calpain substrates have been identified including cytoskeletal proteins, membrane proteins, adhesion molecules, ion transporters, kinases, phosphatases, and phospholipases (Rami 2003).

Calpain activation has been shown to contribute to necrotic cell death (Wang 2000; Liu et al. 2004). While detailed mechanisms for calpain-induced necrosis remain unclear, recent work has shown that calpain-mediated cleavage of the $\mathrm{Na}^{+} / \mathrm{Ca}^{2+}$ exchanger in the plasma membrane results in the sustained secondary intracellular $\mathrm{Ca}^{2+}$ overload and subsequent necrotic cell death (Bano et al. 2005). Calpain may also contribute to the activation of cathepsins by causing lysosomal membrane permeability (LMP), which can lead to release of lysosomal enzymes and necrotic cell death (Yamashima 2004; see below).

\section{Cathepsins and lysosomes}

Another group of proteases that have been implicated in necrosis are the lysosomal cathepsins. Cathepsins are 
grouped into three types by their substrate residues: aspartyl, cysteine, and serine (Rawlings and Barrett 1999). In a healthy cell, cathepsins reside in lysosomes and help break down phagocytosed molecules that are recycled as building blocks for de novo biosynthesis. Cathepsins are fully active in the acidic environment of lysosomes. Under conditions when the lysosomal membrane loses its integrity, cathepsins leak out of lysosomes and, although with less efficiency, digest molecules that are normally not exposed to these proteases, eventually leading to cell death.

A critical point to determine the cell death mode is at the regulation of the lysosomal membrane permeabilization. One of the molecules that have been shown to regulate LMP is sphingosine, one of the sphingolipid metabolites. Sphingolipids are a family of lipids that consist of an amide-linked fatty acid and a long-chain (sphingoid) base. Sphingolipids are structural components of cell membranes (Colombaioni and Garcia-Gil 2004). In response to cell death stimuli, the lysosomal enzyme sphingomyelinase is activated and converts sphingomyelin, the major sphingolipid, into ceramide. Ceramide can be further converted into sphingosine by ceramidase. Both ceramide and sphingosine have been shown to be important signaling molecules that induce apoptosis (Cuvillier 2002). In addition, sphingosine, which is also a detergent, has been shown to cause LMP and cell death in a dose-dependent manner. Sphingosine induces partial lysosomal rupture and apoptosis at low-to-moderate concentrations $(<20 \mu \mathrm{M})$, and extensive lysosomal rupture and necrosis at high concentration $(>20 \mu \mathrm{M}$ ) (Kagedal et al. 2001).

More evidence showing that the LMP plays an important role in necrosis exists, as a recent study has further shown that the trypanolytic factor in human serum, apolipoprotein L-I, can induce trypanosome lysis by forming pores in the lysosomal membranes and causes LMP and lysis of trypanosome (Perez-Morga et al. 2005). On the other hand, heat-shock protein 70 (Hsp70) inhibits this caspase-independent cell death by maintaining lysosomal membrane integrity (Nylandsted et al. 2004). Lysosomes have been proposed as the cell's "suicide bag" (de Duve 1983). Apoptosis, necrosis, and autophagic response can all be initiated from lysosomes. This places lysosomes as a critical control point for cell-fate determination. To which direction the cells go may be dependent on the magnitude of the LMP.

\section{Caspases}

Caspases are categorized into three classes. Two are main components in apoptosis, including initiator caspases $(2,8,9$, and 10), and executioner caspases $(3,6$, and 7$)$. The third class includes inflammatory caspases $(1,4,5,11,12$, and possibly $14,11 / 12$ are murine equivalents of human 4/5) (Fuentes-Prior and Salvesen 2004). The initiator caspases are activated by autocleavage and cleave the executioner caspases to activate them. The executioner caspases cleave other selective cellular components. The activation of the initiator and executioner caspases is a biochemical hallmark of apoptosis, almost never involved in necrosis. In fact, while promoting apoptosis, caspase activation may simultaneously inhibit necrosis to ensure immunological silence during apoptotic cell death. For example, activation of PARP causes necrosis by depleting cellular NAD and ATP pools and is involved in transcriptional regulation of the expression of proinflammatory molecules. The proteolytic cleavage of PARP by caspases thus prevents the necrotic events and inhibits PARP-dependent release of proinflammatory mediators (Zong et al. 2004). Conversely, in PARPdependent necrosis, cellular ATP is rapidly depleted, and apoptosis is inhibited.

Surprisingly, some caspases do not fit easily into the above scheme. For example, caspase- 1 activation contributes to an inflammatory response because it is required for the processing of prointerleukin- $1 \beta$ (proIL-1 $\beta$ ) into mature IL-1 $\beta$ (Thornberry et al. 1992; Kuida et al. 1995; Li et al. 1995). As mentioned above, recent evidence suggests that endogenous caspase- 1 is involved in necrotic cell death of macrophages infected by Salmonella and Shigella.

\section{How might necrosis be an adaptive response for a metazoan organism?}

Apoptosis is defined as a cellular self-destruction process that, under normal physiological conditions, benefits the organism as a whole by getting rid of unwanted or damaged cells. Thus, if we view necrosis as a form of regulated cell death, how may a multicellular organism benefit from necrosis? Accumulating evidence suggests that necrosis may benefit an organism in several ways. Perhaps the most widely accepted consequence of necrosis is that it leads to a proinflammatory response. Considering that necrosis is often initiated by the same insults that would trigger apoptosis when at a lower intensity, one may start to appreciate that necrosis may serve as an organismal warning system of the extent of a toxic exposure. Following minor insults, damaged cells die by apoptosis and are quietly removed by phagocytic cells with minimal interference in normal organismal activities. These dying cells release chemoattractant molecules such as lysophosphatidylcholine (LPC) (Lauber et al. 2003), and display the "eat-me" signals such as phophatidylserine (PS) on the cell surface to ensure the efficient removal of apoptotic cells (Fadok et al. 1992). However, under severe conditions, cells can die in a more dramatic fashion and elicit a host response by alerting and activating the nervous and immune systems. As intracellular molecules are rapidly released into an extracellular environment through disrupted plasma membrane, necrotic cell death may serve to elicit an immune response (Table 1).

Although most of the intracellular content is released out of the plasma membrane during necrosis, a handful of molecules have been identified to date that can elicit necrosis-induced immune signaling. These include the so-called damage-associated molecular pattern (DAMP) molecules, such as S100 family molecules, high-mobil- 
ity group box 1 (HMGB1, also known as amphoterin) protein, purine metabolites, and heat-shock proteins (Zeh and Lotze 2005). Other immunostimulatory molecules that are released by necrotic cells include adenine phosphate (Srinivas et al. 2002; Rich et al. 2003), uric acid (Shi et al. 2003), and heat-shock proteins (Sauter et al. 2000; Berwin et al. 2001; Somersan et al. 2001). As these are cytosolic molecules, presumably during necrotic cell death they are released through disrupted plasma membrane through passive diffusion.

Of these immunostimulating molecules, HMGB1 has been the most thoroughly studied, and the mechanism by which it is released into extracellular space is beginning to be understood. HMGB1 is a chromatin-binding protein that is expressed in all eukaryotic cells. While it functions to stabilize nucleosome formation and may act as a transcriptional regulator, it also acts as a proinflammatory molecule when released into the extracellular environment during necrosis (Scaffidi et al. 2002). Extracellular HMGB1 is a ligand for the macrophage receptor RAGE. HMGB1 binding to macrophages activates production of inflammatory molecules and prosurvival cytokines (Lotze and Tracey 2005). It remains unclear how HMGB1 dissociates from DNA and relocates from the nucleus to extracellular space during necrosis. Evidence exists that PARP may be required for the nucleus-cytosol translocation of HMGB1 in order to prime it for diffusion through disrupted plasma membrane (Zong et al. 2004; D. Ditsworth, W.X. Zong, and C.B. Thompson, unpubl.).

In addition to proinflammatory response, intracellular molecules such as hepatoma-derived growth factor (HDGF) that are released during necrosis can function to activate signaling pathways that promote axonal sprouting and neurite outgrowth in the damaged area, and may also induce cell migration and tumor cell metastasis associated with bad prognosis of the necrotic areas in solid tumors (Zhou et al. 2004).

\section{Closing remarks}

As discussed above, several distinctive features of necrosis have been identified. These include mitochondrial depolarization and depletion of intracellular ATP, disturbance of $\mathrm{Ca}^{2+}$ homeostasis, activation of PARP, activation of nonapoptotic proteases, generation of ROS, and ultimately, disruption of the plasma membrane. Almost all of these events are inter-related and cross-regulated, making it difficult to draw a linear picture of relationships among these events. Apoptosis and necrosis can often be initiated in response to the same types of insults with different doses or intensities. These features have clear biological significance. The redundancy of apoptosis and necrosis as mediators of cell death in response to a given insult may help to ensure that damaged or unwanted cells are eliminated even if the insult eliminates one of these pathways. The dosage dependence of the switch from apoptosis to necrosis in response to the same insults may also alert the organism to the extent of damage and define whether a repair response is required to maintain organismal integrity. While dead cells are quietly removed during apoptosis so that other organismal functions are undisturbed, necrosis triggers an inflammatory response to alert the organism of the need to defend itself against the insult.

Until recently, it has been difficult to determine whether necrosis can be a regulated cell fate in vivo, or whether dead cells with necrotic appearance that are observed result from secondary necrosis of apoptotic cells that are not phagocytosed by neighboring cells. With the development of better biochemistry and genetics tools, it is becoming clear that necrosis can be a regulated form of cell death independent of apoptosis. Chemicals such as $\mathrm{Ca}^{2+}$ chelators, ROS scavengers, PARP inhibitors, calpain inhibitors, and cathepsin inhibitors have been shown to inhibit necrotic cell death. Studies using gene knockout models in C. elegans and mice have also helped demonstrate that necrotic death can be prevented by targeting its molecular components. The delineation of apoptosis and necrosis as distinct cell death pathways has been facilitated by recently developed chemical inhibitors and RNAi. Collectively, these approaches have demonstrated that regulated forms of necrosis exist. In the end, programmed cell necrosis may be just as an important cell fate as apoptosis.

\section{Acknowledgments}

We thank Jianhua Zhang, Dara Ditsworth, Julian Lum, and Ralph Deberardinis for critical readings of the manuscript, and Jessica Joh for technical assistance. We apologize to colleagues whose work is not mentioned. W.X.Z. is supported by the Leukemia and Lymphoma Society and the NCI Howard Temin Award. C.B.T. is supported by grants from the NIH, NCI, Leukemia and Lymphoma Society, and the Abramson Family Cancer Research Institute.

\section{References}

Aarts, M., Iihara, K., Wei, W.L., Xiong, Z.G., Arundine, M., Cerwinski, W., MacDonald, J.F., and Tymianski, M. 2003. A key role for TRPM7 channels in anoxic neuronal death. Cell 115: $863-877$.

Agostinis, P., Buytaert, E., Breyssens, H., and Hendrickx, N. 2004. Regulatory pathways in photodynamic therapy induced apoptosis. Photochem. Photobiol. Sci. 3: 721-729.

Almeida, R.D., Manadas, B.J., Carvalho, A.P., and Duarte, C.B. 2004. Intracellular signaling mechanisms in photodynamic therapy. Biochim. Biophys. Acta 1704: 59-86.

Andreyev, A.Y., Kushnareva, Y.E., and Starkov, A.A. 2005. Mitochondrial metabolism of reactive oxygen species. Biochemistry 70: 200-214.

Ankarcrona, M., Dypbukt, J.M., Bonfoco, E., Zhivotovsky, B., Orrenius, S., Lipton, S.A., and Nicotera, P. 1995. Glutamateinduced neuronal death: A succession of necrosis or apoptosis depending on mitochondrial function. Neuron 15: 961973.

Baggetto, L.G. 1992. Deviant energetic metabolism of glycolytic cancer cells. Biochimie 74: 959-974.

Bai, X., Cerimele, F., Ushio-Fukai, M., Waqas, M., Campbell, P.M., Govindarajan, B., Der, C.J., Battle, T., Frank, D.A., Ye, K., et al. 2003. Honokiol, a small molecular weight natural product, inhibits angiogenesis in vitro and tumor growth in 
vivo. J. Biol. Chem. 278: 35501-35507.

Baines, C.P., Kaiser, R.A., Purcell, N.H., Blair, N.S., Osinska, H., Hambleton, M.A., Brunskill, E.W., Sayen, M.R., Gottlieb, R.A., Dorn, G.W., et al. 2005. Loss of cyclophilin D reveals a critical role for mitochondrial permeability transition in cell death. Nature 434: 658-662.

Bano, D., Young, K.W., Guerin, C.J., Lefeuvre, R., Rothwell, N.J., Naldini, L., Rizzuto, R., Carafoli, E., and Nicotera, P. 2005. Cleavage of the plasma membrane $\mathrm{Na}^{+} / \mathrm{Ca}^{2+}$ exchanger in excitotoxicity. Cell 120: 275-285.

Basso, E., Fante, L., Fowlkes, J., Petronilli, V., Forte, M.A., and Bernardi. P. 2005. Properties of the permeability transition pore in mitochondria devoid of Cyclophilin D. J. Biol. Chem. 280: 18558-18561.

Bauer, D.E., Harris, M.H., Plas, D.R., Lum, J.J., Hammerman, P.S., Rathmell, J.C., Riley, J.L., and Thompson, C.B. 2004. Cytokine stimulation of aerobic glycolysis in hematopoietic cells exceeds proliferative demand. FASEB J. 18: 1303-1305.

Belzacq, A.S., Jacotot, E., Vieira, H.L., Mistro, D., Granville, D.J., Xie, Z., Reed, J.C., Kroemer, G., and Brenner, C. 2001. Apoptosis induction by the photosensitizer verteporfin: Identification of mitochondrial adenine nucleotide translocator as a critical target. Cancer Res. 61: 1260-1264.

Benedict, C.A., Norris, P.S., and Ware, C.F. 2002. To kill or be killed: Viral evasion of apoptosis. Nat. Immunol. 3: 10131018.

Berger, N.A., Sims, J.L., Catino, D.M., and Berger, S.J. 1983. Poly(ADP-ribose) polymerase mediates the suicide response to massive DNA damage: Studies in normal and DNA-repair defective cells. Princess Takamatsu Symp. 13: 219-226.

Berger, A.J., Hart, A.C., and Kaplan, J.M. 1998. G $\alpha$ s-induced neurodegeneration in Caenorhabditis elegans. I. Neurosci. 18: $2871-2880$.

Berridge, M.J. 1995. Capacitative calcium entry. Biochem. J. 312: $1-11$.

Berwin, B., Reed, R.C., and Nicchitta, C.V. 2001. Virally induced lytic cell death elicits the release of immunogenic GRP94/gp96. I. Biol. Chem. 276: 21083-21088.

Bianchi, L., Gerstbrein, B., Frokjaer-Jensen, C., Royal, D.C., Mukherjee, G., Royal, M.A., Xue, J., Schafer, W.R., and Driscoll, M. 2004. The neurotoxic MEC-4(d) DEG/ENaC sodium channel conducts calcium: Implications for necrosis initiation. Nat. Neurosci. 7: 1337-1344.

Boise, L.H. and Collins, C.M. 2001. Salmonella-induced cell death: Apoptosis, necrosis or programmed cell death? Trends Microbiol. 9: 64-67.

Bolton, D.L., Hahn, B.I., Park, E.A., Lehnhoff, L.L., Hornung, F., and Lenardo, M.J. 2002. Death of CD4(+) T-cell lines caused by human immunodeficiency virus type 1 does not depend on caspases or apoptosis. J. Virol. 76: 5094-5107.

Bryant, H.E., Schultz, N., Thomas, H.D., Parker, K.M., Flower, D., Lopez, E., Kyle, S., Meuth, M., Curtin, N.J., and Helleday, T. 2005. Specific killing of BRCA2-deficient tumours with inhibitors of poly(ADP-ribose) polymerase. Nature 434: 913 917.

Cecconi, F., Alvarez-Bolado, G., Meyer, B.I., Roth, K.A., and Gruss, P. 1998. Apaf1 (CED-4 homolog) regulates programmed cell death in mammalian development. Cell 94: 727-737.

Chabner, B.A. and Longo, D.L. 2005. Cancer chemotherapy and biotherapy: Principles and practices. Lippincott Williams and Wilkins, Philadelphia, PA.

Chautan, M., Chazal, G., Cecconi, F., Gruss, P., and Golstein, P. 1999. Interdigital cell death can occur through a necrotic and caspase-independent pathway. Curr. Biol. 9: 967-970.

Chiu, S.M. and Oleinick, N.L. 2001. Dissociation of mitochon- drial depolarization from cytochrome c release during apoptosis induced by photodynamic therapy. Br. J. Cancer 84: 1099-1106.

Chung, S., Gumienny, T.L., Hengartner, M.O., and Driscoll, M. 2000. A common set of engulfment genes mediates removal of both apoptotic and necrotic cell corpses in C. elegans. Nat. Cell. Biol. 2: 931-937.

Cipriani, G., Rapizzi, E., Vannacci, A., Rizzuto, R., Moroni, F., and Chiarugi, A. 2005. Nuclear poly(ADP-ribose) polymerase-1 rapidly triggers mitochondrial dysfunction. I. Biol. Chem. 280: 17227-17234.

Clarke, S.J., McStay, G.P., and Halestrap, A.P. 2002. Sanglifehrin $\mathrm{A}$ acts as a potent inhibitor of the mitochondrial permeability transition and reperfusion injury of the heart by binding to cyclophilin-D at a different site from cyclosporin A. J. Biol. Chem. 277: 34793-34799.

Colombaioni, L. and Garcia-Gil, M. 2004. Sphingolipid metabolites in neural signalling and function. Brain Res. Brain Res. Rev. 46: 328-355.

Cookson, B.T. and Brennan, M.A. 2001. Pro-inflammatory programmed cell death. Trends Microbiol. 9: 113-114.

Crompton, M., Costi, A., and Hayat, L. 1987. Evidence for the presence of a reversible $\mathrm{Ca}^{2+}$-dependent pore activated by oxidative stress in heart mitochondria. Biochem. J. 245: 915-918.

Cuconati, A. and White, E. 2002. Viral homologs of BCL-2: Role of apoptosis in the regulation of virus infection. Genes \& Dev. 16: 2465-2478.

Cuvillier, O. 2002. Sphingosine in apoptosis signaling. Biochim. Biophys. Acta 1585: 153-162.

D'Amours, D., Desnoyers, S., D'Silva, I., and Poirier, G.G. 1999. Poly(ADP-ribosyl)ation reactions in the regulation of nuclear functions. Biochem. J. 342: 249-268.

de Duve, C. 1983. Lysosomes revisited. Eur. I. Biochem. 137: 391-397.

Degterev, A., Huang, Z., Boyce, M., Li, Y., Jagtap, P., Mizushima, N., Cuny, G.D., Mitchison, T.J., Moskowitz, M.A., and Yuan, J. 2005. Chemical inhibitor of nonapoptotic cell death with therapeutic potential for ischemic brain injury. Nat. Chem. Biol. 1: 112-119.

de Murcia, G. and Menissier de Murcia, J. 1994. Poly|ADP-ribose) polymerase: A molecular nick-sensor. Trends Biochem Sci. 19: 172-176.

de Murcia, J.M., Niedergang, C., Trucco, C., Ricoul, M., Dutrillaux, B., Mark, M., Oliver, F.J., Masson, M., Dierich, A., LeMeur, M., et al. 1997. Requirement of poly(ADP-ribose) polymerase in recovery from DNA damage in mice and in cells. Proc. Nat1. Acad. Sci. 94: 7303-7307.

Dennis, S.C., Gevers, W., and Opie, L.H. 1991. Protons in ischemia: Where do they come from; where do they go to? J. Mol. Cell. Cardiol. 23: 1077-1086.

Driscoll, M. and Chalfie, M. 1991. The mec-4 gene is a member of a family of Caenorhabditis elegans genes that can mutate to induce neuronal degeneration. Nature 349: 588-593.

Du, L., Zhang, X., Han, Y.Y., Burke, N.A., Kochanek, P.M., Watkins, S.C., Graham, S.H., Carcillo, J.A., Szabo, C., and Clark, R.S. 2003. Intra-mitochondrial poly(ADP-ribosylation) contributes to NAD+ depletion and cell death induced by oxidative stress. J. Biol. Chem. 278: 18426-18433.

Endres, M., Wang, Z.Q., Namura, S., Waeber, C., and Moskowitz, M.A. 1997. Ischemic brain injury is mediated by the activation of poly(ADP-ribose) polymerase. J. Cereb. Blood Flow Metab. 17: 1143-1151.

Fabris, C., Valduga, G., Miotto, G., Borsetto, L., Jori, G., Garbisa, S., and Reddi, E. 2001. Photosensitization with zinc (II) phthalocyanine as a switch in the decision between apoptosis and necrosis. Cancer Res. 61: 7495-7500. 
Fadok, V.A., Voelker, D.R., Campbell, P.A., Cohen, J.J., Bratton, D.L., and Henson, P.M. 1992. Exposure of phosphatidylserine on the surface of apoptotic lymphocytes triggers specific recognition and removal by macrophages. I. Immunol. 148: 2207-2216.

Farmer, H., McCabe, N., Lord, C.J., Tutt, A.N., Johnson, D.A., Richardson, T.B., Santarosa, M., Dillon, K.J., Hickson, I., Knights, C., et al. 2005. Targeting the DNA repair defect in BRCA mutant cells as a therapeutic strategy. Nature 434: 917-921.

Fatt, P. and Ginsborg, B.L. 1958. The ionic requirements for the production of action potentials in crustacean muscle fibres. J. Physiol. 142: 516-543.

Foo, R.S., Mani, K., and Kitsis, R.N. 2005. Death begets failure in the heart. J. Clin. Invest. 115: 565-571.

Fryer, H.J., Knox, R.J., Strittmatter, S.M., and Kalb, R.G. 1999. Excitotoxic death of a subset of embryonic rat motor neurons in vitro. J. Neurochem. 72: 500-513.

Fuentes-Prior, P. and Salvesen, G.S. 2004. The protein structures that shape caspase activity, specificity, activation and inhibition. Biochem. J. 384: 201-232.

Golab, J., Nowis, D., Skrzycki, M., Czeczot, H., BaranczykKuzma, A., Wilczynski, G.M., Makowski, M., Mroz, P., Kozar, K., Kaminski, R., et al. 2003. Antitumor effects of photodynamic therapy are potentiated by 2-methoxyestradiol. A superoxide dismutase inhibitor. J. Biol. Chem. 278: 407-414.

Goll, D.E., Thompson, V.F., Li, H., Wei, W., and Cong, J. 2003. The calpain system. Physiol. Rev. 83: 731-801.

Gollnick, S.O., Vaughan, L., and Henderson, B.W. 2002. Generation of effective antitumor vaccines using photodynamic therapy. Cancer Res. 62: 1604-1608.

Goossens, V., De Vos, K., Vercammen, D., Steemans, M., Vancompernolle, K., Fiers, W., Vandenabeele, P., and Grooten, J. 1999. Redox regulation of TNF signaling. Biofactors 10: 145156.

Gottlieb, R.A., Gruol, D.L., Zhu, J.Y., and Engler, R.L. 1996. Preconditioning rabbit cardiomyocytes: Role of $\mathrm{pH}$, vacuolar proton ATPase, and apoptosis. J. Clin. Invest. 97: 2391-2398.

Gougeon, M.L. 2003. Apoptosis as an HIV strategy to escape immune attack. Nat. Rev. Immunol. 3: 392-404.

Griffin, D.E. 2005. Neuronal cell death in alphavirus encephalomyelitis. Curr. Top. Microbiol. Immunol. 289: 57-77.

Griffiths, E.J. and Halestrap, A.P. 1995. Mitochondrial non-specific pores remain closed during cardiac ischaemia, but open upon reperfusion. Biochem. J. 307: 93-98.

Guiney, D.G. 2005. The role of host cell death in Salmonella infections. Curr. Top. Microbiol. Immunol. 289: 131-150.

Ha, H.C. and Snyder, S.H. 1999. Poly(ADP-ribose) polymerase is a mediator of necrotic cell death by ATP depletion. Proc. Natl. Acad. Sci. 96: 13978-13982.

Halestrap, A.P., Connern, C.P., Griffiths, E.J., and Kerr, P.M. 1997. Cyclosporin A binding to mitochondrial cyclophilin inhibits the permeability transition pore and protects hearts from ischaemia/reperfusion injury. Mol. Cell. Biochem. 174: $167-172$.

Hartley, A., Stone, J.M., Heron, C., Cooper, J.M., and Schapira, A.H. 1994. Complex I inhibitors induce dose-dependent apoptosis in PC12 cells: Relevance to Parkinson's disease. I. Neurochem. 63: 1987-1990.

Haworth, R.A. and Hunter, D.R. 1979. The $\mathrm{Ca}^{2+}$-induced membrane transition in mitochondria. II. Nature of the $\mathrm{Ca}^{2+}$ trigger site. Arch. Biochem. Biophys. 195: 460-467.

Holler, N., Zaru, R., Micheau, O., Thome, M., Attinger, A., Valitutti, S., Bodmer, J.L., Schneider, P., Seed, B., and Tschopp, J. 2000. Fas triggers an alternative, caspase-8-independent cell death pathway using the kinase RIP as effector molecule. Nat. Immunol. 1: 489-495.

Holt, J.A. 1983. Cancer, a disease of defective glucose metabolism. Med. Hypotheses 10: 133-150.

Hsieh, Y.J., Wu, C.C., Chang, C.J., and Yu, J.S. 2003. Subcellular localization of Photofrin determines the death phenotype of human epidermoid carcinoma A431 cells triggered by photodynamic therapy: When plasma membranes are the main targets. J. Cell Physiol. 194: 363-375.

Huang, M. and Chalfie, M. 1994. Gene interactions affecting mechanosensory transduction in Caenorhabditis elegans. Nature 367: 467-470.

Hueffer, K. and Galan, J.E. 2004. Salmonella-induced macrophage death: Multiple mechanisms, different outcomes. Cell Microbiol. 6: 1019-1025.

Hunter, D.R. and Haworth, R.A. 1979a. The $\mathrm{Ca}^{2+}$-induced membrane transition in mitochondria. I. The protective mechanisms. Arch. Biochem. Biophys. 195: 453-459.

- 1979b. The $\mathrm{Ca}^{2+}$-induced membrane transition in mitochondria. III. Transitional $\mathrm{Ca}^{2+}$ release. Arch. Biochem. Biophys. 195: 468-477.

Inanami, O., Yoshito, A., Takahashi, K., Hiraoka, W., and Kuwabara, M. 1999. Effects of BAPTA-AM and forskolin on apoptosis and cytochrome c release in photosensitized Chinese hamster V79 cells. Photochem. Photobiol. 70: 650-655.

Irusta, P.M. and Hardwick, J.M. 2004. Neuronal apoptosis pathways in Sindbis virus encephalitis. Prog. Mol. Subcell. Biol. 36: 71-93.

Jarvelainen, H.A., Galmiche, A., and Zychlinsky, A. 2003. Caspase-1 activation by Salmonella. Trends Cell. Biol. 13: 204-209.

Kagedal, K., Zhao, M., Svensson, I., and Brunk, U.T. 2001. Sphingosine-induced apoptosis is dependent on lysosomal proteases. Biochem. J. 359: 335-343.

Kawahara, A., Ohsawa, Y., Matsumura, H., Uchiyama, Y., and Nagata, S. 1998. Caspase-independent cell killing by Fasassociated protein with death domain. J. Cell. Biol. 143: $1353-1360$.

Kerr, J.F. 1971. Shrinkage necrosis: A distinct mode of cellular death. J. Pathol. 105: 13-20.

Kerr, J.F., Wyllie, A.H., and Currie, A.R. 1972. Apoptosis: A basic biological phenomenon with wide-ranging implications in tissue kinetics. Br. J. Cancer 26: 239-257.

Kim, M.Y., Zhang, T., and Kraus, W.L. 2005. Poly(ADP-ribosyl)ation by PARP-1: 'PAR-laying' NAD+ into a nuclear signal. Genes \& Dev. 19: 1951-1967.

Kokoszka, J.E., Waymire, K.G., Levy, S.E., Sligh, J.E., Cai, J., Jones, D.P., MacGregor, G.R., and Wallace, D.C. 2004. The ADP/ATP translocator is not essential for the mitochondrial permeability transition pore. Nature 427: 461-465.

Korswagen, H.C., Park, J.H., Ohshima, Y., and Plasterk, R.H. 1997. An activating mutation in a Caenorhabditis elegans Gs protein induces neural degeneration. Genes \& Dev. 11: 1493-1503.

Kuida, K., Lippke, J.A., Ku, G., Harding, M.W., Livingston, D.J., Su, M.S., and Flavell, R.A. 1995. Altered cytokine export and apoptosis in mice deficient in interleukin-1 $\beta$ converting enzyme. Science 267: 2000-2003.

Lauber, K., Bohn, E., Krober, S.M., Xiao, Y.J., Blumenthal, S.G., Lindemann, R.K., Marini, P., Wiedig, C., Zobywalski, A., Baksh, S., et al. 2003. Apoptotic cells induce migration of phagocytes via caspase-3-mediated release of a lipid attraction signal. Cell 113: 717-730.

Lemasters, J.J. 1999. V. Necrapoptosis and the mitochondrial permeability transition: Shared pathways to necrosis and apoptosis. Am. J. Physiol. 276: G1-G6.

Lenardo, M.J., Angleman, S.B., Bounkeua, V., Dimas, J., Duvall, 
M.G., Graubard, M.B., Hornung, F., Selkirk, M.C., Speirs, C.K., Trageser, C., et al. 2002. Cytopathic killing of peripheral blood CD4(+) T lymphocytes by human immunodeficiency virus type 1 appears necrotic rather than apoptotic and does not require env. J. Virol. 76: 5082-5093.

Li, P., Allen, H., Banerjee, S., Franklin, S., Herzog, L., Johnston, C., McDowell, J., Paskind, M., Rodman, L., Salfeld, J., et al. 1995. Mice deficient in IL-1 $\beta$-converting enzyme are defective in production of mature IL-1 $\beta$ and resistant to endotoxic shock. Cell 80: 401-411.

Li, Y.Z., Li, C.J., Pinto, A.V., and Pardee, A.B. 1999. Release of mitochondrial cytochrome $\mathrm{C}$ in both apoptosis and necrosis induced by $\beta$-lapachone in human carcinoma cells. Mol. Med. 5: 232-239.

Lindsten, T., Ross, A.J., King, A., Zong, W.X., Rathmell, J.C., Shiels, H.A., Ulrich, E., Waymire, K.G., Mahar, P., Frauwirth, K., et al. 2000. The combined functions of proapoptotic Bcl-2 family members bak and bax are essential for normal development of multiple tissues. Mol. Cell 6: 13891399.

Lindsten, T., Golden, J.A., Zong, W.X., Minarcik, J., Harris, M.H., and Thompson, C.B. 2003. The proapoptotic activities of Bax and Bak limit the size of the neural stem cell pool. J. Neurosci. 23: 11112-11119.

Liu, X., Van Vleet, T., and Schnellmann, R.G. 2004. The role of calpain in oncotic cell death. Annu. Rev. Pharmacol. Toxicol. 44: 349-370.

Logue, S.E., Gustafsson, A.B., Samali, A., and Gottlieb, R.A. 2005. Ischemia/reperfusion injury at the intersection with cell death. J. Mol. Cell. Cardiol. 38: 21-33.

Lotze, M.T. and Tracey, K.J. 2005. High-mobility group box 1 protein (HMGB1): Nuclear weapon in the immune arsenal. Nat. Rev. Immunol. 5: 331-342.

Lum, J.J., Bauer, D.E., Kong, M., Harris, M.H., Li, C., Lindsten, T., and Thompson, C.B. 2005. Growth factor regulation of autophagy and cell survival in the absence of apoptosis. Cell 120: $237-248$.

Majno, G. and Joris, I. 1995. Apoptosis, oncosis, and necrosis. An overview of cell death. Am. J. Pathol. 146: 3-15.

Marnett, L.J. 2000. Oxyradicals and DNA damage. Carcinogenesis 21: 361-370.

Marzo, I., Brenner, C., Zamzami, N., Jurgensmeier, J.M., Susin, S.A., Vieira, H.L., Prevost, M.C., Xie, Z., Matsuyama, S., Reed, J.C., et al. 1998. Bax and adenine nucleotide translocator cooperate in the mitochondrial control of apoptosis. Science 281: 2027-2031.

McConkey, D.J. and Orrenius, S. 1996. The role of calcium in the regulation of apoptosis. J. Leukoc. Biol. 59: 775-783.

McCormack, J.G., Halestrap, A.P., and Denton, R.M. 1990. Role of calcium ions in regulation of mammalian intramitochondrial metabolism. Physiol. Rev. 70: 391-425.

McStay, G.P., Clarke, S.J., and Halestrap, A.P. 2002. Role of critical thiol groups on the matrix surface of the adenine nucleotide translocase in the mechanism of the mitochondrial permeability transition pore. Biochem. J. 367: 541-548.

Miccoli, L., Beurdeley-Thomas, A., De Pinieux, G., Sureau, F., Oudard, S., Dutrillaux, B., and Poupon, M.F. 1998. Lightinduced photoactivation of hypericin affects the energy metabolism of human glioma cells by inhibiting hexokinase bound to mitochondria. Cancer Res. 58: 5777-5786.

Nagata, S. 1997. Apoptosis by death factor. Cell 88: 355-365.

Nakagawa, T., Shimizu, S., Watanabe, T., Yamaguchi, O., Otsu, K., Yamagata, H., Inohara, H., Kubo, T., and Tsujimoto, Y. 2005. Cyclophilin D-dependent mitochondrial permeability transition regulates some necrotic but not apoptotic cell death. Nature 434: 652-658.
Narita, M., Shimizu, S., Ito, T., Chittenden, T., Lutz, R.J., Matsuda, H., and Tsujimoto, Y. 1998. Bax interacts with the permeability transition pore to induce permeability transition and cytochrome c release in isolated mitochondria. Proc. Natl. Acad. Sci. 95: 14681-14686.

Neumar, R.W. 2000. Molecular mechanisms of ischemic neuronal injury. Ann. Emerg. Med. 36: 483-506.

Nicolli, A., Basso, E., Petronilli, V., Wenger, R.M., and Bernardi, P. 1996. Interactions of cyclophilin with the mitochondrial inner membrane and regulation of the permeability transition pore, and cyclosporin A-sensitive channel. I. Biol. Chem. 271: 2185-2192.

Nicotera, P., Leist, M., and Manzo, L. 1999. Neuronal cell death: A demise with different shapes. Trends Pharmacol. Sci. 20: 46-51.

Nishimura, Y. and Lemasters, J.J. 2001. Glycine blocks opening of a death channel in cultured hepatic sinusoidal endothelial cells during chemical hypoxia. Cell Death Differ. 8: 850-858.

Nordberg, J. and Arner, E.S. 2001. Reactive oxygen species, antioxidants, and the mammalian thioredoxin system. Free Radic. Biol. Med. 31: 1287-1312.

Nylandsted, J., Gyrd-Hansen, M., Danielewicz, A., Fehrenbacher, N., Lademann, U., Hoyer-Hansen, M., Weber, E., Multhoff, G., Rohde, M., and Jaattela, M. 2004. Heat shock protein 70 promotes cell survival by inhibiting lysosomal membrane permeabilization. J. Exp. Med. 200: 425-435.

Ohgoh, M., Shimizu, H., Ogura, H., and Nishizawa, Y. 2000. Astroglial trophic support and neuronal cell death: Influence of cellular energy level on type of cell death induced by mitochondrial toxin in cultured rat cortical neurons. J. Neurochem. 75: 925-933.

Oppenheim, R.W. 1991. Cell death during development of the nervous system. Annu. Rev. Neurosci. 14: 453-501.

Padanilam, B.J. 2003. Cell death induced by acute renal injury: A perspective on the contributions of apoptosis and necrosis. Am. J Physiol. Renal Physiol. 284: F608-F627.

Pastorino, J.G., Chen, S.T., Tafani, M., Snyder, J.W., and Farber, J.L. 1998. The overexpression of Bax produces cell death upon induction of the mitochondrial permeability transition. J. Biol. Chem. 273: 7770-7775.

Perez-Morga, D., Vanhollebeke, B., Paturiaux-Hanocq, F., Nolan, D.P., Lins, L., Homble, F., Vanhamme, L., Tebabi, P., Pays, A., Poelvoorde, P., et al. 2005. Apolipoprotein L-I promotes trypanosome lysis by forming pores in lysosomal membranes. Science 309: 469-472.

Pfeiffer, T., Schuster, S., and Bonhoeffer, S. 2001. Cooperation and competition in the evolution of ATP-producing pathways. Science 292: 504-507.

Phalipon, A. and Sansonetti, P.J. 2003. Shigellosis: Innate mechanisms of inflammatory destruction of the intestinal epithelium, adaptive immune response, and vaccine development. Crit. Rev. Immunol. 23: 371-401.

Proskuryakov, S.Y., Gabai, V.L., and Konoplyannikov, A.G. 2002. Necrosis is an active and controlled form of programmed cell death. Biochemistry 67: 387-408.

Purves, D., Snider, W.D., and Voyvodic, J.T. 1988. Trophic regulation of nerve cell morphology and innervation in the autonomic nervous system. Nature 336: 123-128.

Putney Jr., J.W. 1986. A model for receptor-regulated calcium entry. Cell Calcium 7: 1-12.

Rami, A. 2003. Ischemic neuronal death in the rat hippocampus: The calpain-calpastatin-caspase hypothesis. Neurobiol. Dis. 13: 75-88.

Rathmell, J.C., Vander Heiden, M.G., Harris, M.H., Frauwirth, K.A., and Thompson, C.B. 2000. In the absence of extrinsic signals, nutrient utilization by lymphocytes is insufficient 
to maintain either cell size or viability. Mol. Cell 6: 683-692. Rathmell, J.C., Fox, C.J., Plas, D.R., Hammerman, P.S., Cinalli, R.M., and Thompson, C.B. 2003. Akt-directed glucose metabolism can prevent Bax conformation change and promote growth factor-independent survival. Mol. Cell. Biol. 23: 7315-7328.

Rawlings, N.D. and Barrett, A.J. 1999. MEROPS: The peptidase database. Nucleic Acids Res. 27: 325-331.

Reiners Jr., J.J., Caruso, J.A., Mathieu, P., Chelladurai, B., Yin, X.M., and Kessel, D. 2002. Release of cytochrome c and activation of pro-caspase-9 following lysosomal photodamage involves Bid cleavage. Cell Death Differ. 9: 934-944.

Rich, P.B., Douillet, C.D., Mahler, S.A., Husain, S.A., and Boucher, R.C. 2003. Adenosine triphosphate is released during injurious mechanical ventilation and contributes to lung edema. J. Trauma 55: 290-297.

Sadoul, R. 1998. Bcl-2 family members in the development and degenerative pathologies of the nervous system. Cell Death Differ. 5: 805-815.

Salomon, A.R., Voehringer, D.W., Herzenberg, L.A., and Khosla, C. 2000. Understanding and exploiting the mechanistic basis for selectivity of polyketide inhibitors of $\mathrm{F}(0) \mathrm{F}(1)$-ATPase. Proc. Nat1. Acad. Sci. 97: 14766-14771.

Saris, N.E. and Carafoli, E. 2005. A historical review of cellular calcium handling, with emphasis on mitochondria. Biochemistry 70: 187-194.

Sattler, R. and Tymianski, M. 2001. Molecular mechanisms of glutamate receptor-mediated excitotoxic neuronal cell death. Mol. Neurobiol. 24: 107-129.

Sauter, B., Albert, M.L., Francisco, L., Larsson, M., Somersan, S., and Bhardwaj, N. 2000. Consequences of cell death: Exposure to necrotic tumor cells, but not primary tissue cells or apoptotic cells, induces the maturation of immunostimulatory dendritic cells. J. Exp. Med. 191: 423-434.

Scaffidi, P., Misteli, T., and Bianchi, M.E. 2002. Release of chromatin protein HMGB1 by necrotic cells triggers inflammation. Nature 418: 191-195.

Schinzel, A.C., Takeuchi, O., Huang, Z., Fisher, J.K., Zhou, Z., Rubens, J., Hetz, C., Danial, N.N., Moskowitz, M.A., and Korsmeyer, S.J. 2005. Cyclophilin D is a component of mitochondrial permeability transition and mediates neuronal cell death after focal cerebral ischemia. Proc. Natl. Acad. Sci. 102: $12005-12010$

Shchepina, L.A., Popova, E.N., Pletjushkina, O.Y., and Chernyak, B.V. 2002. Respiration and mitochondrial membrane potential are not required for apoptosis and anti-apoptotic action of Bcl-2 in HeLa cells. Biochemistry 67: 222226.

Shi, Y., Evans, J.E., and Rock, K.L. 2003. Molecular identification of a danger signal that alerts the immune system to dying cells. Nature 425: 516-521.

Somersan, S., Larsson, M., Fonteneau, J.F., Basu, S., Srivastava, P., and Bhardwaj, N. 2001. Primary tumor tissue lysates are enriched in heat shock proteins and induce the maturation of human dendritic cells. J. Immunol. 167: 4844-4852.

Srinivas, S.P., Mutharasan, R., and Fleiszig, S. 2002. Shear-induced ATP release by cultured rabbit corneal epithelial cells. Adv. Exp. Med. Biol. 506: 677-685.

Steenbergen, C., Perlman, M.E., London, R.E., and Murphy, E. 1993. Mechanism of preconditioning. Ionic alterations. Circ. Res. 72: 112-125.

Stout, A.K., Raphael, H.M., Kanterewicz, B.I., Klann, E., and Reynolds, I.J. 1998. Glutamate-induced neuron death requires mitochondrial calcium uptake. Nat. Neurosci. 1: 366373.

Strehler, E.E. and Treiman, M. 2004. Calcium pumps of plasma membrane and cell interior. Curr. Mol. Med. 4: 323-335.

Suzuki, K. and Sorimachi, H. 1998. A novel aspect of calpain activation. FEBS Lett. 433: 1-4.

Suzuki, K., Hata, S., Kawabata, Y., and Sorimachi, H. 2004. Structure, activation, and biology of calpain. Diabetes 53: S12-S18.

Syntichaki, P., Xu, K., Driscoll, M., and Tavernarakis, N. 2002. Specific aspartyl and calpain proteases are required for neurodegeneration in C. elegans. Nature 419: 939-944.

Tagliarino, C., Pink, J.J., Dubyak, G.R., Nieminen, A.L., and Boothman, D.A. 2001. Calcium is a key signaling molecule in $\beta$-lapachone-mediated cell death. I. Biol. Chem. 276: 19150-19159.

Thornberry, N.A., Bull, H.G., Calaycay, J.R., Chapman, K.T., Howard, A.D., Kostura, M.J., Miller, D.K., Molineaux, S.M., Weidner, J.R., Aunins, J., et al. 1992. A novel heterodimeric cysteine protease is required for interleukin-1 $\beta$ processing in monocytes. Nature 356: 768-774.

Treinin, M. and Chalfie, M. 1995. A mutated acetylcholine receptor subunit causes neuronal degeneration in C. elegans. Neuron 14: 871-877.

Uehlinger, P., Zellweger, M., Wagnieres, G., Juillerat-Jeanneret, L., van den Bergh, H., and Lange, N. 2000. 5-Aminolevulinic acid and its derivatives: Physical chemical properties and protoporphyrin IX formation in cultured cells. J. Photochem. Photobiol. B 54: 72-80.

Vercammen, D., Beyaert, R., Denecker, G., Goossens, V., Van Loo, G., Declercq, W., Grooten, J., Fiers, W., and Vandenabeele, P. 1998. Inhibition of caspases increases the sensitivity of L929 cells to necrosis mediated by tumor necrosis factor. J. Exp. Med. 187: 1477-1485.

Waldmann, R., Champigny, G., Voilley, N., Lauritzen, I., and Lazdunski, M. 1996. The mammalian degenerin MDEG, an amiloride-sensitive cation channel activated by mutations causing neurodegeneration in Caenorhabditis elegans. I. Biol. Chem. 271: 10433-10436.

Wang, K.K. 2000. Calpain and caspase: Can you tell the difference? Trends Neurosci. 23: 20-26.

Wang, Z.Q., Stingl, L., Morrison, C., Jantsch, M., Los, M., Schulze-Osthoff, K., and Wagner, E.F. 1997. PARP is important for genomic stability but dispensable in apoptosis. Genes \& Dev. 11: 2347-2358.

Waring, P. 2005. Redox active calcium ion channels and cell death. Arch. Biochem. Biophys. 434: 33-42.

Watson, A.J., Askew, J.N., and Benson, R.S. 1995. Poly(adenosine diphosphate ribose) polymerase inhibition prevents necrosis induced by $\mathrm{H} 2 \mathrm{O} 2$ but not apoptosis. Gastroenterology 109: 472-482.

Wei, M.C., Zong, W.X., Cheng, E.H., Lindsten, T., Panoutsakopoulou, V., Ross, A.J., Roth, K.A., MacGregor, G.R., Thompson, C.B., and Korsmeyer, S.J. 2001. Proapoptotic BAX and BAK: A requisite gateway to mitochondrial dysfunction and death. Science 292: 727-730.

Weinrauch, Y. and Zychlinsky, A. 1999. The induction of apoptosis by bacterial pathogens. Annu. Rev. Microbiol. 53: $155-187$.

Whitacre, C.M., Satoh, T.H., Xue, L., Gordon, N.H., and Oleinick, N.L. 2002. Photodynamic therapy of human breast cancer xenografts lacking caspase-3. Cancer Lett. 179: 4349.

Woodgate, A., MacGibbon, G., Walton, M., and Dragunow, M. 1999. The toxicity of 6-hydroxydopamine on PC12 and P19 cells. Brain Res. Mol. Brain Res. 69: 84-92.

Xiong, Z.G., Zhu, X.M., Chu, X.P., Minami, M., Hey, J., Wei, W.L., MacDonald, J.F., Wemmie, J.A., Price, M.P., Welsh, M.J., et al. 2004. Neuroprotection in ischemia: Blocking cal- 
cium-permeable acid-sensing ion channels. Cell 118: 687698.

Xu, K., Tavernarakis, N., and Driscoll, M. 2001. Necrotic cell death in C. elegans requires the function of calreticulin and regulators of $\mathrm{Ca}^{2+}$ release from the endoplasmic reticulum. Neuron 31: 957-971.

Yamashima, T. 2004. $\mathrm{Ca}^{2+}$-dependent proteases in ischemic neuronal death: A conserved 'calpain-cathepsin cascade' from nematodes to primates. Cell Calcium 36: 285-293.

Yermolaieva, O., Leonard, A.S., Schnizler, M.K., Abboud, F.M., and Welsh, M.J. 2004. Extracellular acidosis increases neuronal cell calcium by activating acid-sensing ion channel $1 \mathrm{a}$. Proc. Natl. Acad. Sci. 101: 6752-6757.

Ying, W., Garnier, P., and Swanson, R.A. 2003. NAD+ repletion prevents PARP-1-induced glycolytic blockade and cell death in cultured mouse astrocytes. Biochem. Biophys. Res. Commun. 308: 809-813.

Ying, W., Alano, C.C., Garnier, P., and Swanson, R.A. 2005. $\mathrm{NAD}+$ as a metabolic link between DNA damage and cell death. J. Neurosci. Res. 79: 216-223.

Yoshida, H., Kong, Y.Y., Yoshida, R., Elia, A.J., Hakem, A., Hakem, R., Penninger, J.M., and Mak, T.W. 1998. Apaf1 is required for mitochondrial pathways of apoptosis and brain development. Cell 94: 739-750.

Yu, S.W., Wang, H., Poitras, M.F., Coombs, C., Bowers, W.J., Federoff, H.J., Poirier, G.G., Dawson, T.M., and Dawson, V.L. 2002. Mediation of poly(ADP-ribose) polymerase-1-dependent cell death by apoptosis-inducing factor. Science 297: 259-263.

Yuan, J., Lipinski, M., and Degterev, A. 2003. Diversity in the mechanisms of neuronal cell death. Neuron 40: 401-413.

Zeh III, H.J. and Lotze, M.T. 2005. Addicted to death: Invasive cancer and the immune response to unscheduled cell death. J. Immunother. 28: 1-9.

Zhang, Y. and Bliska, J.B. 2005. Role of macrophage apoptosis in the pathogenesis of Yersinia. Curr. Top. Microbiol. Immunol. 289: 151-173.

Zhou, Z., Yamamoto, Y., Sugai, F., Yoshida, K., Kishima, Y., Sumi, H., Nakamura, H., and Sakoda, S. 2004. Hepatomaderived growth factor is a neurotrophic factor harbored in the nucleus. J. Biol. Chem. 279: 27320-27326.

Zong, W.X., Ditsworth, D., Bauer, D.E., Wang, Z.Q., and Thompson, C.B. 2004. Alkylating DNA damage stimulates a regulated form of necrotic cell death. Genes \& Dev. 18: $1272-1282$.

Zweier, J.L., Flaherty, J.T., and Weisfeldt, M.L. 1987. Direct measurement of free radical generation following reperfusion of ischemic myocardium. Proc. Natl. Acad. Sci. 84: 1404-1407. 


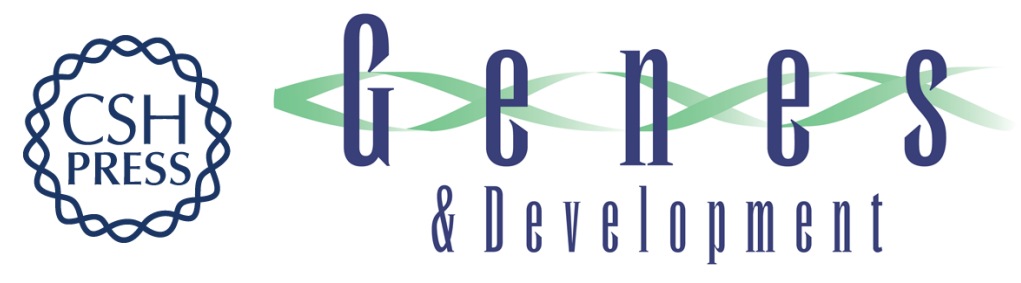

\section{Necrotic death as a cell fate}

Wei-Xing Zong and Craig B. Thompson

Genes Dev. 2006, 20:

Access the most recent version at doi:10.1101/gad.1376506

References This article cites 161 articles, 48 of which can be accessed free at: http://genesdev.cshlp.org/content/20/1/1.full.html\#ref-list-1

License

Email Alerting Receive free email alerts when new articles cite this article - sign up in the box at the top Service right corner of the article or click here.

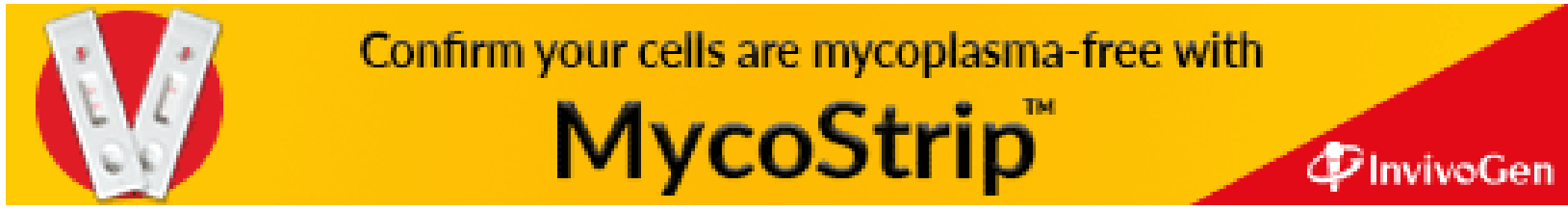

